\title{
A novel galacturonide from Xanthomonas campestris
}

\author{
Alicia Baldessari, $\dagger$ Luis IelPi and Marcelo A. DanKerT* \\ Instituto de Investigaciones Bioquimicas 'Fundacion Campomar', Facultad de Ciencias Exactas y Naturales y CONICET, \\ Av. Patricias Argentinas 435, 1405 Buenos Aires, Argentina
}

(Received 28 November 1989; revised 16 March 1990; accepted 26 March 1990)

\begin{abstract}
Enzyme preparations from Xanthomonas campestris incubated in the presence of UDP- $\left[{ }^{14} \mathrm{C}\right] \mathrm{GlcA}$ and $\mathrm{Mg}^{2+}$ produced a lipophilic galacturonide with unusual properties. It was easily degraded by both mild acid treatment $\left(0.01 \mathrm{M}-\mathrm{HCl}, 100^{\circ} \mathrm{C}, 10 \mathrm{~min}\right)$ and mild alkali treatment $(0.06 \mathrm{M}-\mathrm{NaOH}$, room temperature, $5 \mathrm{~min})$ releasing free $\left[{ }^{14} \mathrm{C}\right]$ galacturonic acid. The galacturonide appeared to be a single compound with one negative charge, as judged by TLC, paper electrophoresis and chromatography, LH-20 gel filtration and DEAE-cellulose column chromatography. Competition experiments indicated that the true glycosyl donor was UDP-GalA, in agreement with the detection of UDP-GlcA-4-epimerase activity in the crude enzyme preparation. The transglycosidase activity was located mainly in the membrane fraction. UDP inhibited the reaction and even produced some loss of label, suggesting an easily reversible reaction. UMP had almost no effect.
\end{abstract}

\section{Introduction}

Xanthomonas campestris, a plant pathogen, produces an exopolysaccharide, xanthan gum, of extensive industrial application (Sandford, 1979; Sutherland, 1985). Work in this laboratory has shown that, in vitro, the repeating unit of this polysaccharide, which contains glucose, mannose and glucuronic acid, is sequentially assembled on a prenyl diphosphate derivative and subsequently polymerized into xanthan gum (Ielpi et al., 1981). The sugar donors are UDP-Glc, GDP-Man and UDP-GlcA. These studies involved the characterization of a series of radiolabelled prenyl phosphosugars. It was observed that when the label was in UDP- $\left[{ }^{14} \mathrm{C}\right] \mathrm{GlcA}$, a highly lipophilic compound was formed that did not participate in the biosynthesis of the polysaccharide.

In this paper, some properties of this lipid-bound uronic acid' derivative and its synthesizing system are described. The word 'lipid' simply means that the compound is soluble in organic but not in aqueous solvents.

$\dagger$ Present address: Departamento de Quimica Organica, Facultad de Ciencias Exactas y Naturales, Universidad de Buenos Aires, 1428 Buenos Aires, Argentina.

Abbreviations: GlcA, glucuronic acid; GalA, galacturonic acid; ManA, mannuronic acid; UDP-Glc, uridine diphosphate glucose; GDP-Man, guanosine diphosphate mannose; UDP-GlcA, uridine diphosphate glucuronic acid; UDP-GalA, uridine diphosphate galacturonic acid; EDC, 1-ethyl-3-(3-dimethylaminopropyl)carbodiimide.

\section{Methods}

Chemicals. UDP- $\left[{ }^{4} \mathrm{C}\right]$ glucuronic acid $\left[285-329 \mathrm{mCi} \mathrm{mmol}^{-1}(10 \cdot 5-\right.$ $12.2 \mathrm{GBq} \mathrm{mmol}^{-1}$ )] was prepared as previously described (Couso et al., 1982). A mixture of UDP- $\left[{ }^{14} \mathrm{C}\right]$ glucuronic acid $(75 \%)$ and UDP$\left[{ }^{14}\right]$ galacturonic acid $(25 \%)$ [200 $\left.\mathrm{mCi} \mathrm{mmol}^{-1}\left(7.4 \mathrm{GBq} \mathrm{mmol}^{-1}\right)\right]$ was prepared with enzymes from Xanthomonas campestris or Rhizobium meliloti 131 (M. Bravo and M. A. Dankert, unpublished results) and is referred to as UDP-[ $\left[{ }^{14} \mathrm{C}\right] \mathrm{GlcA}-\mathrm{GalA} .\left[{ }^{14} \mathrm{C}\right]$ Galactose-P-prenol and $\left[{ }^{14} \mathrm{C}\right]$ glucose-P-P-prenol were synthesized with enzymes from Acetobacter xylinum as reported previously (Romero et al., 1977; Garcia et al., 1974). $\left[{ }^{14} \mathrm{C}\right]$ Glucose-P-dolichol was a kind gift from $\mathrm{Dr} \mathrm{N}$. Behrens, of this Institute. $\left[{ }^{14} \mathrm{C}\right] \mathrm{Palmitic}$ acid was purchased from New England Nuclear. Other chemicals were obtained from commercial sources.

Enzyme preparations. The standard enzyme preparation consisted of cells of Xanthomonas campestris strain NRRL B-1459, grown, harvested and treated with EDTA as previously described (Ielpi et al., 1981). A membrane fraction obtained from fresh cells (about $500 \mathrm{mg}$ ) was resuspended in $10 \mathrm{ml} 70 \mathrm{~mm}$-Tris/ $\mathrm{HCl}$ buffer, $\mathrm{pH} 8.2$, and fractionated with an X-press (Biox, Sweden). The disrupted cell suspension was brought to $10 \mathrm{mM}-\mathrm{MgCl}_{2}$ and $3 \mathrm{~mm}$-EDTA in $70 \mathrm{~mm}$-Tris/ $\mathrm{HCl}, \mathrm{pH} 8 \cdot 2$, and incubated at $40{ }^{\circ} \mathrm{C}$ for $15 \mathrm{~min}$ in the presence of deoxyribonuclease II (Sigma, D4138) $\left(0.1 \mathrm{mg} \mathrm{ml}^{-1}\right)$. Coarse fragments were removed by centrifugation at $8700 \mathrm{~g}$ for $20 \mathrm{~min}$ and the supernatant was centrifuged at $130000 \mathrm{~g}$ for $3 \mathrm{~h}$. Two fractions were obtained : a supernatant, termed the 'soluble fraction', which contained $25-30 \mathrm{mg}$ protein $\mathrm{ml}^{-1}$, and a pellet, which, resuspended in $70 \mathrm{mM}-\mathrm{Tris} / \mathrm{HCl}$ buffer, $\mathrm{pH} 8.2$, was termed 'insoluble membrane fraction' and contained $30-33 \mathrm{mg}$ protein $\mathrm{ml}^{-1}$. Protein concentration was determined by the Lowry method. The enzyme preparations contained endogenous donors as well as acceptors of galacturonic acid residues, in varying amounts for the different batches. 
Standard incubation assays. The reaction mixture contained the following components: $70 \mathrm{mM}$-Tris/HCl buffer, $\mathrm{pH} 8$ 8; EDTA-treated whole cells (or 'soluble or insoluble membrane fractions', where indicated) $\left(0 \cdot 9-1 \mathrm{mg}\right.$ protein), $16 \mathrm{~mm}-\mathrm{MgCl}_{2}$ and $0.01 \mathrm{~mm}-\mathrm{UDP}-$ $\left[{ }^{14} \mathrm{C}\right] \mathrm{GlcA}$. The reaction mixtures (final volume $70 \mu \mathrm{l}$ ) were incubated at $15{ }^{\circ} \mathrm{C}$ for $30 \mathrm{~min}$; the reaction was stopped by adding $0.1 \mathrm{ml}$ butan-1$\mathrm{ol}$ and mixing by vortexing. The mixture was centrifuged in a benchtop Eppendorf centrifuge at 14000 r.p.m. for $2 \mathrm{~min}$ and the upper layer, containing the lipophilic incorporation products, carefully removed. This extraction was repeated three times and the combined butanol layers were washed with water in a similar way $(4 \times 0.1 \mathrm{ml}$ each). Radioactivity incorporated into the butanol extract was counted in Bray's solution (Bray, 1960) with a Tri-Carb scintillation counter (Packard).

Chemical treatments. Mild acid hydrolysis, at $\mathrm{pH} 2(0.01 \mathrm{M}-\mathrm{HCl})$ and $100{ }^{\circ} \mathrm{C}$ for $10 \mathrm{~min}$, mild alkaline treatment $[0.06 \mathrm{M}-\mathrm{NaOH}$ in chloroform/methanol $(4: 1, \mathrm{v} / \mathrm{v})$ at room temperature for $5 \mathrm{~min}]$ and phenol treatment $\left(50 \%, w / v\right.$, phenol at $68-70^{\circ} \mathrm{C}$ for $\left.2 \mathrm{~h}\right)$ were done as previously described (Garcia et al., 1974).

Reduction of carboxyl groups to the respective alcohols was done by the method of Taylor \& Conrad (1972) modified in the following way. The butanolic extract was treated with $10 \mathrm{mg}$ solid EDC [1-ethyl-3-(3dimethylaminopropyl) carbodiimide] for $2 \mathrm{~h}$ at room temperature maintaining a constant $\mathrm{pH}$ of 4.7 with $0.5 \mathrm{M}-\mathrm{HCl}$ before slowly adding $0.1 \mathrm{ml} 3 \mathrm{M}$-sodium borohydride in butanol. During this operation the $\mathrm{pH}$ was maintained at 7 by addition of $4 \mathrm{M}-\mathrm{HCl}$. This procedure was done at $0^{\circ} \mathrm{C}$ to avoid hydrolysis of the product, before leaving the reaction mixture at room temperature for $4 \mathrm{~h}$. After this period, $0.1 \mathrm{ml}$ water and sufficient Dowex $50\left(\mathrm{H}^{+}\right.$form $)$resin were added to lower the aqueous phase to $\mathrm{pH} 4$. The two phases were separated by centrifugation. About $90 \%$ of the radioactivity was recovered in the butanolic phase.

Catalytic reduction was done by bubbling $\mathrm{H}_{2}$ gas into the butanolic extract containing (2-4 mg) finely divided $\mathrm{Pt}, \mathrm{PtO}_{2}$ (Adam's catalyst, Aldrich) or $10 \% \mathrm{Pd}$ on activated carbon (Aldrich) at room temperature for the times indicated in each case. A butanol/water partition was then done as described above.

Chromatography and electrophoresis. Gel-filtration column chromatography on Sephadex LH-20 $(1.2 \times 160 \mathrm{~cm})$ in $0.1 \mathrm{M}$-ammonium acetate in $99 \%$ methanol and ion-exchange column chromatography on DEAE-cellulose $(1.2 \times 58 \mathrm{~cm})$ in $99 \%$ methanol with a $0-0.4 \mathrm{M}$ ammonium acetate gradient (in a total volume of $400 \mathrm{ml}$ ) were done as previously described (Dankert et al., 1966; Garcia et al., 1974) collecting 150 fractions of $0.5 \mathrm{ml}$ and $3.0 \mathrm{ml}$ respectively. Where indicated, the samples were desalted by LH-20 gel-filtration with $99 \%$ methanol.

Paper chromatography and electrophoresis were done on Schleicher and Schuell 2043 paper as previously reported (Garcia et al., 1974) using the following solvents: A, 1.2 M-pyridinium acetate buffer, pH 6.5; B, 0.1 M-sodium molybdate buffer, pH 5.0 (Bourne et al., 1961); $\mathrm{C}$, nitromethane/acetic acid/ethanol/boric acid saturated solution $(8: 1: 1: 1$, by vol.); $D$, ethanol/concentrated ammonia $(7: 3, v / v) ; E$, propan-2-ol/acetic acid/water (27:4:9, by vol.) (Tung \& Nordin, 1968). TLC was done on Silica Gel G plates $(250 \mu \mathrm{m}$ thick, Merck) with chloroform/methanol/water $(60: 25: 4$, by vol.) as solvent (Pont Lezica et al., 1975).

Enzyme treatments: Galactose oxidase assays (Sigma, type V) were done as described previously (Garcia et al., 1974); the oxidation product $\left(R_{\mathrm{gal}} 0.52\right)$ was detected by paper chromatography in solvent $\mathrm{E}$.

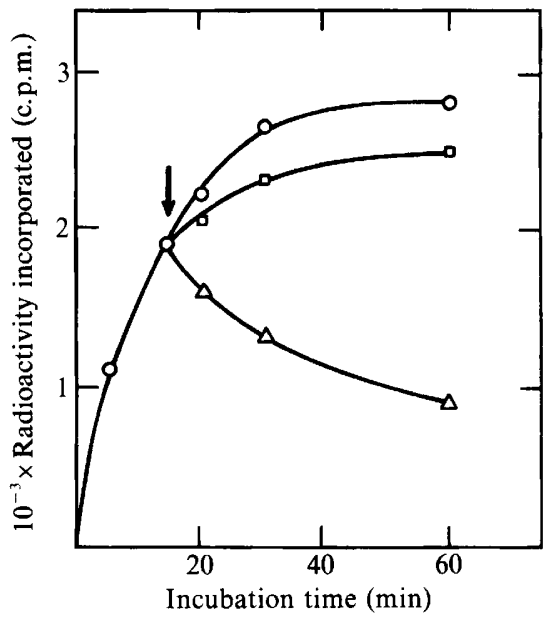

Fig. 1. Effect of UMP $(\square)$ and UDP $(\triangle)$ on the time-course of $\left[{ }^{14} \mathrm{C}\right]$ incorporation into butanol soluble compounds. $O$, Control. The standard incubation mixture was scaled up 15 times and $0.05 \mathrm{ml}$ samples were taken at the times indicated. After $15 \mathrm{~min}$ incubation (arrowed) a sample of the remaining incubation mixture was transferred to a tube containing UMP and another one to a tube containing UDP, both at $2.0 \mathrm{mM}$ final concentration. At the times indicated $0.05 \mathrm{ml}$ samples were taken, extracted with butanol and counted as described in Methods.

\section{Results}

\section{Incorporation of ${ }^{14} \mathrm{C}$-label into a lipidic compound}

Incorporation of radioactivity from UDP- $\left[{ }^{14} \mathrm{C}\right] \mathrm{GlcA}$ into a butanol-soluble compound was dependent on the presence of $\mathrm{Mg}^{2+}$; no incorporation was observed in its absence and the maximum incorporation was reached at $16 \mathrm{mM}$. Under the standard conditions used the incorporation reached a plateau after $30 \mathrm{~min}$ incubation. Incorporation increased linearly with increased amounts of enzyme until a plateau was reached at about $1 \mathrm{mg}$ protein. A plot of incorporated radioactivity versus UDP- $\left[{ }^{14} \mathrm{C}\right] \mathrm{Glc} A$ concentration indicated that under the conditions of the assay $(10 \mu \mathrm{M})$ there was a large excess of lipid acceptor in the preparation.

Increasing amounts of UDP inhibited incorporation of radioactivity into the butanolic extract and at $0.75 \mathrm{mM}$-UDP a $75-80 \%$ inhibition plateau was reached. UMP had almost no effect. This difference in behaviour is clearly shown in a time-course experiment in which UMP was added after $15 \mathrm{~min}$ incubation; the radioactivity incorporated was only slightly decreased (Fig. 1). If UDP was substituted for UMP, incorporation of radioactivity was abruptly interrupted, and even some delabelling could be observed (Fig. 1). This result suggests that UDP is possibly one of the reaction products and, as such, can reverse incorporation. 


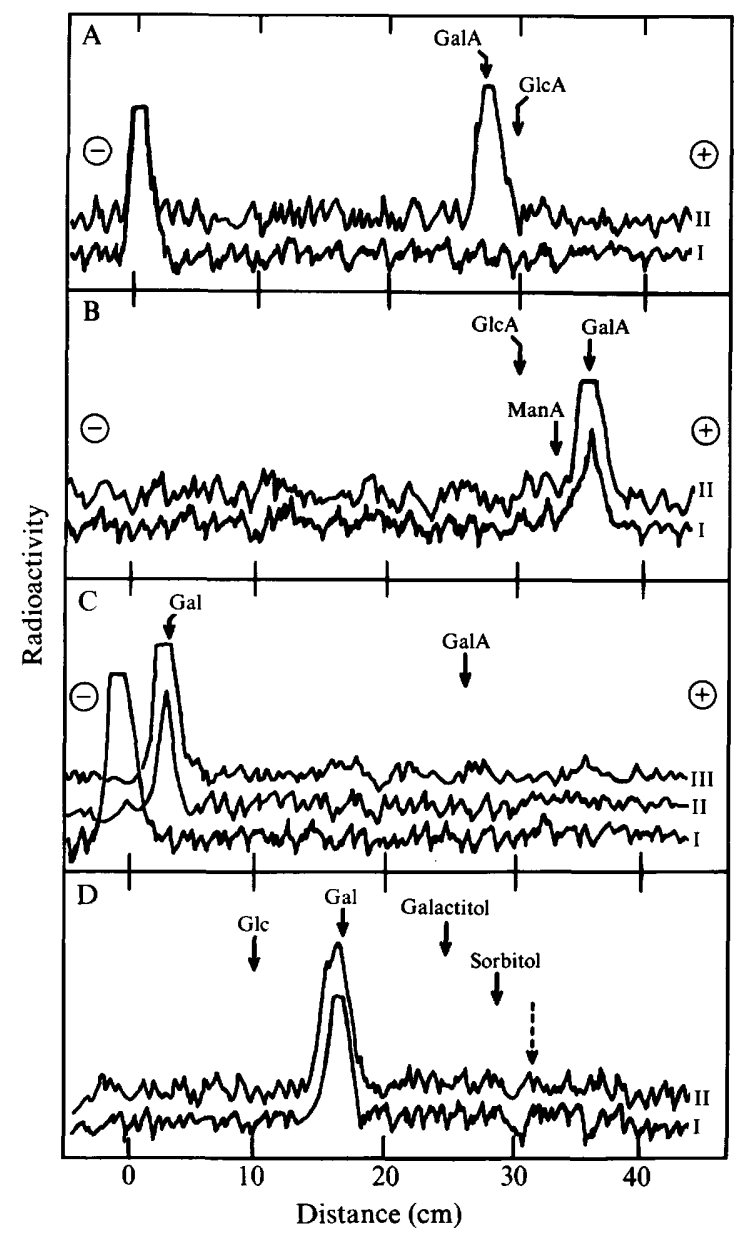

Fig. 2. Paper chromatography and electrophoresis of the incorporation product. A, Paper electrophoresis with buffer A of a butanol extract of the standard incubation mixture without treatment (I) and after mild acid hydrolysis (0.01 M- $\left.\mathrm{HCl}, 100^{\circ} \mathrm{C}, 10 \mathrm{~min}\right)$ (II). B, Paper electrophoresis with buffer $B$ of the butanol extract after mild acid hydrolysis (I) or mild alkaline treatment $(0.06 \mathrm{M}-\mathrm{NaOH}$, room temperature, $5 \mathrm{~min})$ (II). C, Paper electrophoresis with buffer A of "carboxyl reduced lipidbound $\left[{ }^{14} \mathrm{C}\right] \mathrm{GalA}$ ' without treatment (I) and after mild acid hydrolysis (II) or mild alkaline treatment (III). D, Paper chromatography with buffer $\mathrm{C}$ of 'carboxyl reduced lipid-bound $\left[{ }^{14} \mathrm{C}\right] \mathrm{GalA}$ ' after mild acid hydrolysis (I) or mild alkaline treatment (II). The arrows indicated the mobility of the respective standards and the dotted arrow, the solvent front. The maximum point on the radioactivity scale corresponds to 100 c.p.m.

\section{Isolation and chemical properties of lipid-bound uronic acid'}

Analysis of the butanolic extract by paper chromatography with solvent $\mathrm{D}$ showed only one radioactive component, $R_{F} 0 \cdot 84$, indicative of a lipophilic compound (not shown) (Garcia et al., 1974). This was confirmed by paper electrophoresis with buffer $\mathbf{A}$ in which all the radioactivity remained at the origin, as expected for a water-insoluble substance (Fig. 2A) (Couso et al., 1982).

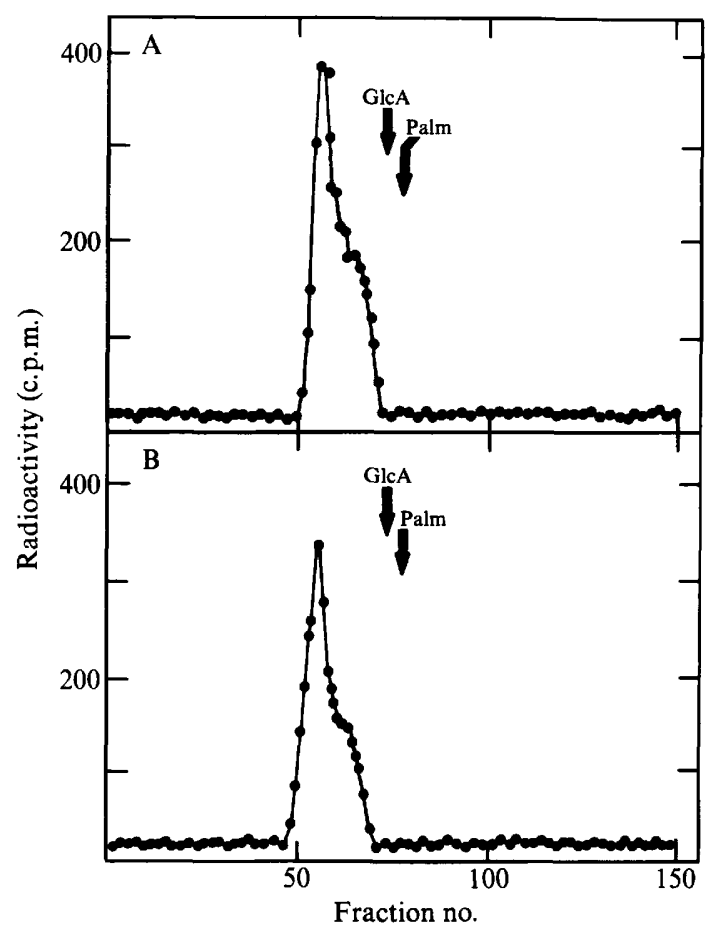

Fig. 3. LH-20 column chromatography of 'lipid-bound uronic acid' and 'reduced lipid-bound uronic acid'. The arrows indicate the elution position of $\left[{ }^{14} \mathrm{C}\right]$ glucuronic acid and $\left[{ }^{14} \mathrm{C}\right]$ palmitic acid (Palm) used as standards. The 'lipid-bound $\left[{ }^{14} \mathrm{C}\right]$ ronic acid' sample (40000 c.p.m.) consisted of a butanol extract of a standard incubation scaled up 10 times. Samples $(0.1 \mathrm{ml})$ were counted for radioactivity (A). The 'reduced lipid-bound [ $\left.{ }^{14} \mathrm{C}\right]$ uronic acid' sample (20000 c.p.m.) was obtained by esterification with EDC and sodium borohydride reduction, as indicated in Methods. Samples $(0.1 \mathrm{ml}$ each) were counted for radioactivity (B).

TLC showed a single radioactive compound with a mobility intermediate between $\left[{ }^{14} \mathrm{C}\right]$ glucose-P-dolichol and $\left[{ }^{14} \mathrm{C}\right]$ galactose-P-prenol (not shown). The profile obtained by gel filtration on a Sephadex LH-20 column showed one peak with a small shoulder eluting slightly ahead of a GlcA standard (Fig. 3A).

DEAE-cellulose column chromatography gave only one component, eluting at $0.12 \mathrm{M}$-ammonium acetate (Fig. 4A). Under the same conditions $\left[{ }^{14} \mathrm{C}\right]$ galactose-Pprenol is eluted at $0 \cdot 11 \mathrm{M}$ - and $\left[{ }^{14} \mathrm{C}\right]$ glucose-P-P-prenol at $0.23 \mathrm{M}$-ammonium acetate. These results suggest that the radioactive compound formed should have only the negative charge of the uronic acid since the galactose derivative, which has a phosphate residue with one primary hydroxyl group, is eluted at about the same concentration. The diphosphate bridge of the glucose derivative, which was retained for longer in the column, has two primary hydroxyl groups.

Mild acid hydrolysis ( $\mathrm{pH} 2,100^{\circ} \mathrm{C}, 10 \mathrm{~min}$ ) of the butanol-soluble compound released practically all the radioactivity into the water phase (Table 1). Unexpect- 


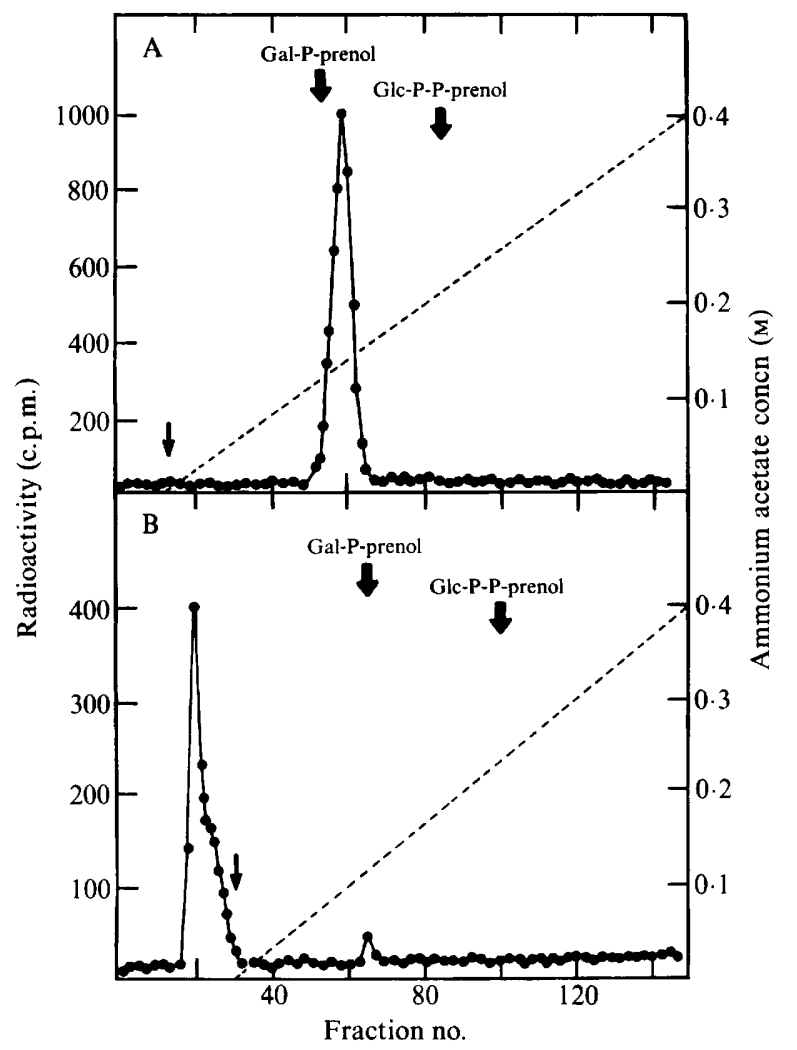

Fig. 4. DEAE-cellulose column chromatography of "lipid-bound uronic acid' and 'reduced lipid-bound uronic acid'. The ammonium acetate gradient (--) was started at fractions 13 and 30 respectively (small arrow). The large arrows indicate the elution positions of $\left[{ }^{14} \mathrm{C}\right] \mathrm{Gal}-\mathrm{P}-$ prenol and $\left[{ }^{14} \mathrm{C}\right]$ Glc-P-P-prenol used as standards. The lipid-bound $\left[{ }^{14} \mathrm{C}\right]$ uronic acid' sample (30000 c.p.m.) consisted of a butanol extract of a standard incubation mixture scaled up 5 times. Samples $(0.5 \mathrm{ml})$ were counted for radioactivity (A). The 'reduced lipid-bound $\left[{ }^{14} \mathrm{C}\right]$ uronic acid' sample (12000 c.p.m.) was obtained by esterification with EDC and sodium borohydride reduction, as indicated in Methods. Samples $(0.5 \mathrm{ml}$ each) were counted for radioactivity (B).

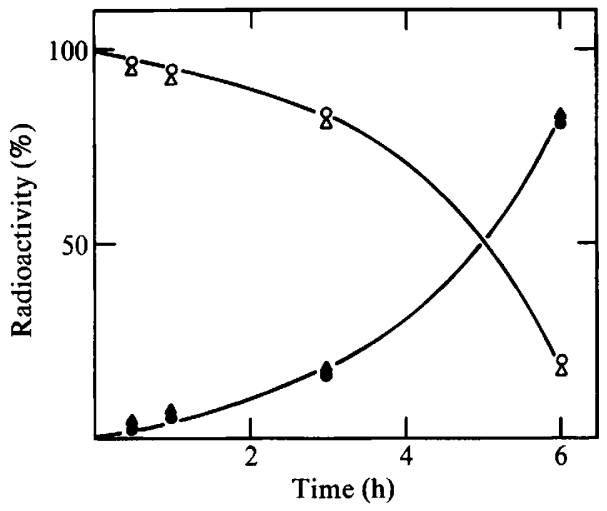

Fig. 5. Catalytic reduction of 'lipid-bound $\left[{ }^{14} \mathrm{C}\right] \mathrm{GalA}$. Butanol extracts (20000-30000 c.p.m.) were treated with $\mathrm{H}_{2}$ in the presence of $\mathrm{PtO}_{2}$ $(2 \mathrm{mg})(\mathrm{O}, 0)$ or $10 \% \mathrm{Pd}$ on activated carbon $(2 \mathrm{mg})(\triangle, \Delta)$ at room temperature. Samples $(0.25 \mathrm{ml} \mathrm{each})$ were taken at the times indicated and partitioned with water $(0.25 \mathrm{ml})$ as indicated in Methods. Radioactivity in the butanolic $(O, \triangle)$ and aqueous phases $(\Theta, \Delta)$ was counted in Bray's solution.

edly, when submitted to paper electrophoresis with buffer $\mathrm{A}$ this material behaved as galacturonic acid (Fig. 2A). This result was confirmed by paper electrophoresis with buffer B, a system that clearly distinguishes between galacturonic, glucuronic and mannuronic acids (Fig. 2B).

Phenol treatment, a procedure that splits allylic phosphate-prenol linkages (Garcia et al., 1974) releasing the phosphosugar moiety, had almost no effect on lipidbound galacturonic acid ('lipid-bound GalA') even after $2 \mathrm{~h}$ treatment at $70^{\circ} \mathrm{C}$ (Table 1 ).

Mild alkaline hydrolysis $(0.06 \mathrm{M}-\mathrm{NaOH}$, room temperature, $5 \mathrm{~min}$ ) liberated all the radioactivity (Table 1 ) as galacturonic acid, as judged by paper electrophoresis with buffers A and B (Fig. 2B).

\section{Table 1. Lability of different samples to chemical degradation treatments}

Samples $\left(5000-15000\right.$ c.p.m.) were treated as follows. $\mathrm{H}^{+}: 0.01 \mathrm{M}-\mathrm{HCl}, 100^{\circ} \mathrm{C}, 10 \mathrm{~min} . \mathrm{OH}^{-}: 0.06 \mathrm{M}-$ $\mathrm{NaOH}$ in chloroform/methanol $(4: 1, \mathrm{v} / \mathrm{v})$, room temperature, $5 \mathrm{~min}$. Phenol: $50 \%(\mathrm{w} / \mathrm{v})$ phenol, $70^{\circ} \mathrm{C}$, $2 \mathrm{~h} . \mathrm{H}_{2}-\mathrm{Pt}$ : room temperature, $15 \mathrm{~min}$. In each case butanol/water partitions were done as indicated in Methods. For clarity, only the radioactivity in the water phase (as a percentage of the initial radioactivity) is indicated.

\begin{tabular}{|c|c|c|c|c|}
\hline \multirow[b]{2}{*}{ Sample } & \multicolumn{4}{|c|}{$\begin{array}{l}\text { Percentage radioactivity released } \\
\text { after treatment with: }\end{array}$} \\
\hline & $\mathbf{H}^{+}$ & $\mathrm{OH}^{-}$ & Phenol & $\mathbf{H}_{2}-\mathrm{Pt}$ \\
\hline Prenol-P- $\left[{ }^{14} \mathrm{C}\right] \mathrm{Gal}$ & 100 & 10 & 82 & 95 \\
\hline 'Lipid-bound-[ $\left.{ }^{14} \mathrm{C}\right] \mathrm{GalA}$ ' & 87 & 95 & 8 & 2 \\
\hline 'Carboxyl reduced lipid-bound $\left[{ }^{14} \mathrm{C}\right] \mathrm{GalA}$ ' & 67 & 93 & 9 & 1 \\
\hline $\mathrm{H}_{2}-\mathrm{Pt}$ treated 'lipid-bound $\left[{ }^{14} \mathrm{C}\right] \mathrm{GalA}{ }^{*}$ & 80 & 94 & - & _- \\
\hline $\mathrm{H}_{2}-\mathrm{PtO}_{2}$ treated 'lipid-bound $\left[{ }^{14} \mathrm{C}\right] \mathrm{GalA}$ '* & 80 & 94 & - & - \\
\hline $\mathrm{H}_{2}-\mathrm{Pd}$ treated 'lipid-bound $\left[{ }^{14} \mathrm{C}\right] \mathrm{GalA} \mathrm{A}^{*}$ & 82 & 95 & _- & _- \\
\hline $\mathrm{H}_{2}-\mathrm{Pt}$ treated "carboxyl reduced lipid-bound $\left[{ }^{14} \mathrm{C}\right] \mathrm{GalA}$ * & 62 & 94 & - & - \\
\hline
\end{tabular}

* Samples were treated as indicated for $3 \mathrm{~h}$. 
Table 2. Effect of unlabelled UDP-GlcA and UDP-GalA on incorporation of radioactivity into the butanolic extract

Conditions were as for the standard incubation assay, except for the addition of the unlabelled sugar donors at $0.1 \mathrm{mM}$ or $0.5 \mathrm{~mm}$ final concentration, as indicated in each case. ND, Not detectable.

\begin{tabular}{lcr}
\hline \hline & \multicolumn{2}{c}{ Radioactivity incorporated } \\
\cline { 2 - 3 } Substrate donor & [c.p.m. (mg protein) $\left.{ }^{-1}\right]$ & $\%$ \\
\hline UDP-[ $\left[{ }^{14} \mathrm{C}\right]$ GlcA & 1552 & 100 \\
UDP-[14 $]$ GlcA + UDP-GalA $(1: 10)$ & 117 & 7 \\
UDP- $\left[{ }^{14} \mathrm{C}\right]$ GlcA + UDP-GalA $(1: 50)$ & ND & 0 \\
UDP-[ $\left[{ }^{4} \mathrm{C}\right]$ GlcA + UDP-GlcA $(1: 10)$ & 620 & 40 \\
UDP- $\left[{ }^{14} \mathrm{C}\right]$ GlcA + UDP-GlcA $(1: 50)$ & 152 & 10 \\
\hline \hline
\end{tabular}

Table 3. Enzyme location and substrate donor specificity

The standard assay was done as described in Methods except for the enzyme preparation or the sugar donor, which were as indicated in each case.

\begin{tabular}{|c|c|c|}
\hline Enzyme & Substrate donor $(10 \mu \mathrm{M})^{*}$ & $\begin{array}{c}\text { Radioactivity } \\
\text { incorporated } \\
\left.\text { [c.p.m. (mg protein) })^{-1}\right]\end{array}$ \\
\hline EDTA-treated cells & & 2150 \\
\hline Membrane fraction & UDP- $\left[{ }^{14} \mathrm{C}\right]$ GlcA & 1838 \\
\hline Soluble fraction & & 186 \\
\hline EDTA-treated cells & & 2916 \\
\hline Membrane fraction $\}$ & UDP-[ $\left[{ }^{4} \mathrm{C}\right]$ GlcA-GalA & 4036 \\
\hline Soluble fraction & & 170 \\
\hline
\end{tabular}

*The UDP- $\left[{ }^{14} \mathrm{C}\right] \mathrm{GlcA}-\mathrm{GalA}$ mixture contained $75 \%$ and $25 \%$ of the glucuronic and galacturonic acid derivatives, respectively.

'Lipid-bound GalA' was resistant to hydrogenolysis. After $3 \mathrm{~h}$ treatment with $\mathrm{H}_{2}$ using either $\mathrm{Pt}, \mathrm{PtO}_{2}$ or $10 \%$ $\mathrm{Pd}$ on activated carbon as catalysts about $85 \%$ of the radioactivity still remained in the butanolic phase (Fig. 5). These treatments did not change substantially the acid and alkali lability of the butanol-soluble galacturonide (Table 1). Longer treatments $(6 \mathrm{~h})$ with any of the catalysts released $80-85 \%$ of the radioactivity into the water phase (Fig. 5). This material was identified as free galacturonic acid by paper electrophoresis with buffers $\mathrm{A}$ and $\mathrm{B}$, which distinguishes galacturonic acid from galacturonitol.

These results taken together indicated that either the true sugar donor was UDP-GalA or that once transferred to the acceptor lipid the glucuronic acid residue was epimerized to galacturonic acid. This latter possibility was ruled out by competition experiments with unlabelled UDP-GalA (Table 2). In the presence of unlabelled UDP-GlcA or UDP-GalA incorporation was lowered to $40 \%$ and $7 \%$, respectively, for a $1: 10$ molar ratio; for a 1:50 molar ratio incorporation of radioactivity was lowered to $10 \%$ with UDP-GlcA and was not detectable with UDP-GalA. Furthermore, incorporation from the mixture of UDP-[14 C]GlcA and UDP$\left[{ }^{14} \mathrm{C}\right] \mathrm{GalA}$ (UDP- $\left[{ }^{14} \mathrm{C}\right] \mathrm{GlcA}-\mathrm{GalA}$ ) was higher than from pure UDP-[ $\left.{ }^{14} \mathrm{C}\right] \mathrm{GlcA}$ (Table 3 ). This approach was confirmed by the characterization of a UDP-GlcA-4epimerase activity in these enzyme preparations (M. Bravo \& M. A. Dankert, unpublished results).

\section{Carboxyl reduced lipid-bound GalA}

'Lipid-bound $\left[{ }^{14} \mathrm{C}\right] \mathrm{GalA}$ ', purified by DEAE-cellulose column chromatography and desalted by LH-20 gelfiltration, was esterified in the presence of EDC and treated with sodium borohydride in order to reduce the carboxyl groups to primary alcohols. More than $87 \%$ of the label remained butanol soluble. Gel filtration of this material through a Sephadex LH-20 column gave a profile similar to that obtained with 'lipid-bound GalA' (Fig. 3B).

'Carboxyl reduced lipid-bound GalA', chromatographed on a DEAE-cellulose column, was eluted before starting the ammonium acetate elution gradient, instead of at $0.12 \mathrm{M}$ as observed for the non-reduced product, 
indicating that the negative charge had been lost (Fig. 4B). This was confirmed by mild acid hydrolysis of the 'carboxyl reduced lipid-bound GalA' which liberated a neutral compound, ${ }^{14} \mathrm{C}$-labelled, as judged by paper electrophoresis with buffer A (Fig. 2C), which had the mobility of $\left[{ }^{14} \mathrm{C}\right]$ galactose by paper chromatography with solvent $\mathrm{C}$ (Fig. 2D). Its identity was confirmed by incubation with galactose oxidase. Consistently, the acid lability of the 'carboxyl reduced lipid-bound GalA' was slightly lowered (Table 1).

'Carboxyl reduced lipid-bound GalA' was not affected by phenol treatment nor by catalytic reduction, but was degraded to $\left[{ }^{14} \mathrm{C}\right]$ galactose by mild alkaline hydrolysis (Table 1 and Fig. 2D).

\section{Enzyme location}

Experiments done with disrupted cells and UDP$\left[{ }^{14} \mathrm{C}\right] \mathrm{GlcA}$ as donor indicated that galacturonic acid transfer activity in the 'membrane fraction' was ten times higher than in the 'soluble fraction'. Nevertheless, the activity was maximal with EDTA-treated cells (Table 3). When the UDP-[ $\left[{ }^{14} \mathrm{C}\right] \mathrm{GlcA}-\mathrm{GalA}$ mixture was substituted for UDP-[ $\left.{ }^{14} \mathrm{C}\right] \mathrm{GlcA}$ the maximum incorporation was obtained with the 'membrane fraction'; EDTA-treated cells incorporated $72 \%$ and the 'soluble fraction $4.2 \%$ of the radioactivity present in the 'membrane fraction' (Table 3). These results agree with the fact that most of the UDP-GlcA-4-epimerase activity is recovered in the 'soluble fraction' (M. Bravo \& M. A. Dankert, unpublished results).

\section{Discussion}

The results presented above show that EDTA-treated $X$. campestris cells synthesize in vitro a highly lipophilic galacturonide, with unusual chemical properties. The enzyme preparation also contains UDP-GlcA-4-epimerase activity since UDP- $\left[{ }^{14} \mathrm{C}\right] \mathrm{GlcA}$ can be used as sugar donor. The sequence of reactions can be represented as follows.

$$
\text { UDP-GlcA } \rightleftharpoons \text { UDP-GalA }
$$

$\mathrm{Mg}^{2+}$

$$
\text { UDP-GalA + lipid } \rightleftharpoons \text { lipid-bound GalA + UDP }
$$

Reaction (1) has been described for other systems (Fan \& Feingold, 1972; Feingold et al., 1960; Gaunt et al., 1974) and a study of the present enzyme, which is $\mathrm{Mg}^{2+}$ independent, will be reported elsewhere.

Reaction (2), on the contrary, has an absolute requirement for $\mathrm{Mg}^{2+}$, the optimal concentration being $16 \mathrm{~mm}$. The reaction is reversible, as suggested by the loss of label observed in the presence of excess UDP (Fig. 1). Only the sugar moiety is transferred since UMP has almost no effect on the reaction (Fig. 1) and no radioactivity was detected in the butanol extract when $[\beta-32$ P]UDP-GlcA was used as donor (not shown). Furthermore no evidence for the presence of a phosphate group in 'lipid-bound GalA' was detected (see below).

The transferase activity is located mainly in the insoluble 'membrane fraction' (Table 3) and could not be totally separated from reaction (1). For this reason, no further studies were made.

The properties of the galacturonide formed, called 'lipid-bound GalA' are quite unusual and differ from those of prenyl-phosphosugars and other glycosides so far described (Ballou, 1984; Pont Lezica et al., 1975).

'Lipid-bound GalA' seems to be fairly homogeneous. TLC analysis showed only one radioactive substance, although the profile obtained by LH-20 gel filtration could indicate either some heterogeneity or partial adsorption to the gel. The carboxyl reduced derivative demonstrates a similar pattern indicating that this group is not the cause of tailing.

DEAE-cellulose column chromatography of 'lipidbound GalA' produced a single sharp peak in the position expected for a compound with only one negative charge (as the Gal-P-lipid used as standard) attributable to the galacturonic acid moiety. This interpretation was confirmed by reduction of the carboxyl group to obtain the galactose derivative: the DEAE-cellulose elution pattern of 'carboxyl reduced lipid-bound GalA' showed that the negative charge had been lost.

'Lipid-bound GalA' was very sensitive to mild acid, as expected for a prenyl-phosphosugar but was degraded neither by phenol treatment nor by catalytic reduction in contrast to allylic prenols (Table 1). In this respect it behaves as a dolichol derivative (Pont Lezica et al., 1975).

Most surprisingly, 'lipid-bound GalA' was degraded by mild alkali, liberating free galacturonic acid. This was an unexpected property. Sugar monophosphate prenols, both allylic and dolicholic, are resistant to this treatment, and the diphosphate derivatives are either resistant or produce the 1,2-cyclic phosphate ester of the sugar, provided the hydroxyl groups at carbons 1 and 2 are in the cis-position and the latter is not substituted (Garcia et al., 1974). For the 'lipid-bound GalA' these possibilities are ruled out because it does not contain phosphate residues. Regular glycosides are relatively acid- or alkaliresistant (Ballou, 1984) and the only reported derivatives easily degraded under both conditions are some enolic (or vinylic) glycosides (Mead et al., 1958; Wakabayashi et al., 1964). To test this possibility and to gain some insight into the nature of the aglycone the 'lipid-bound' derivatives were treated with $\mathrm{H}_{2}$ in the presence of 
different catalysts (Rylander, 1969). 'Lipid-bound GalA' and 'carboxyl-reduced lipid-bound GalA' were resistant for short reduction times (Table 1). Longer treatments led to liberation of free galacturonic acid or galactose, respectively. The $\mathrm{Pd}$ catalyst is reputed to favour reduction of double bonds prior to hydrogenolysis (Alden \& Davies, 1968). This would cause a glycosidic-enol linkage to become a regular hydroxylic linkage, providing greater stability to acid and/or alkali degradation. No such changes were observed with the 'lipid-bound GalA' (Table 1). Since the nature of the lipid or aglycone moiety is unknown, the structure of this part of the molecule is currently under study.

To our knowledge this is the first acid- and alkalilabile lipid-linked galacturonide reported. The synthesis of related lipid-bound glucuronides has been described in chicken liver (Cummings \& Roth, 1982) and in Acetobacter xylinum (Couso et al., 1986). Some of their properties coincide with those of 'lipid-bound GalA', for example acid- and alkali-lability, but both compounds have an extra negative charge, attributed to a phosphate group in the chicken liver substance and of unknown origin in the A. xylinum derivative.

Very little can be said about the function of "lipidbound GalA'. Its lipophilic nature and the lability of its glycosidic linkage would make it an adequate galacturonyl donor at the cytoplasmic membrane level. It could also be a lipophilic uronic acid reservoir. We are tempted to suggest that, together with the chicken liver and the $A$. xylinum glucuronides, the $X$. campestris gluconide belongs to a new type of 'activated sugar'.

D-Galacturonic acid has been reported to be a minor component of a phenol-soluble lipopolysaccharide from $X$. campestris (Hickman \& Ashwell, 1966) and a galacturonyl phosphate ester of unknown function has also been described in this organism (Volk, 1968). We have no evidence to relate these compounds to the "lipidbound GalA' and the UDP-GalA here described, but so far they are the only GalA-containing derivatives reported in $X$. campestris.

We acknowledge Marta Bravo and Susana Raffo for the preparation of sugar nucleotides. We thank Dr Sara H. Goldemberg and Dr Roberto $\mathrm{O}$. Couso for discussion of the manuscript.

\section{References}

Alden, C. K. \& DAvies, D. J. (1968). Hydrogenolysis reactions of some polychlorinated norborn-2-enes, and the synthesis of 1,4-dichloronorborn-2-ene. Journal of the Chemical Society C700-704.

Ballou, C. E. (1984). Alkali-sensitive glycosides. Advances in Carbohydrate Chemistry 9, 59-95.

Bourne, J., Hutson, D. M. \& Weigel, H. (1961). Complexes between molybdate and acyclic polyhydroxy-compounds. Journal of the Chemical Society Part I, 35-38.
BraY, G. A. (1960). A simple efficient liquid scintillator for counting aqueous solutions in a liquid scintillator counter. Analytical Biochemistry 1, 279-285.

Couso, R. O., Ielpi, L., Garcia, R. C. \& Dankert, M. A. (1982). Biosynthesis of polysaccharides in Acetobacter xylinum. Sequential synthesis of a heptasaccharide diphosphate prenol. European Journal of Biochemistry 153, 617-627.

Couso, R. O., Inon de Iannino, N. \& Dankert, M. A. (1986). Characterization of a lipid-linked glucuronic acid derivative in Acetobacter xylinum preparations. Anales de la Asociacion Quimica Argentina 74, 783-793.

Cummings, R. D. \& Roth, S. (1982). The discovery of a lipid-linked glucuronide and its synthesis by chicken liver. Journal of Biological Chemistry 257, 1755-1764.

Dankert, M. A., Wright, A., Kelly, W. S. \& Robbins, P. W. (1966). Isolation, purification, and properties of the lipid-linked intermediates of O-antigen biosynthesis. Archives of Biochemistry and Biophysics 116, 425-435.

FAN, D. \& FEINGOLD, D. S. (1972). Biosynthesis of uridine diphosphate D-xylose. V. UDP-D-glucuronate and UDP-D-galacturonate carboxy-lyase of Ampullariella digitata. Archives of Biochemistry and Biophysics 148, 576-580.

Feingold, D. S., Neufeld, E. F. \& Hassid, W. Z. (1960). The 4epimerization and decarboxylation of uridine diphosphate $D$ glucuronic acid by extracts from Phaseolus aureus seedlings. Journal of Biological Chemistry 235, 910-913.

Garcia, R. C., Recondo, E. \& Dankert, M. A. (1974). Polysaccharide biosynthesis in Acetobacter xylinum. Enzymatic synthesis of lipid diphosphate and monophosphate sugars. European Journal of Biochemistry 43, 93-105.

GaunT, M. A., Maitia, U. S. \& ANBel, H. (1974). Uridine diphosphate galacturonate 4-epimerase from the blue-green alga Anabaena flosaquae. Journal of Biological Chemistry 249, 2366-2372.

HICKMAN, J. \& ASHWELL, G. (1966). Isolation of a bacterial lipopolysaccharide from Xanthomonas campestris containing 3acetamido-3,6-dideoxy-D-galactose and D-rhamnose. Journal of Biological Chemistry 241, 1424-1428.

IelPI, L., Couso, R. \& Dankert, M. A. (1981). Lipid-linked intermediates in the biosynthesis of xanthan gum. FEBS Letters 130 , 253-256.

Mead, J. A., Smith, J. N. \& Williams, R. T. (1958). Studies in detoxication. 71. The metabolism of hydroxycoumarins. Biochemical Journal 68, 61-67.

Pont lezica, R., Brett, Ch. T., Romero Martinez, P. \& Dankert, M. A. (1975). A glucose acceptor in plants with the properties of an $\alpha$ saturated polyprenylmonophosphate. Biochemical and Biophysical Research Communications 66, 980-987.

Romero, P., Garcia, R. C. \& Dankert, M. A. (1977). Synthesis of polyprenol-monophosphate-galactose by Acetobacter xylinum. Molecular and Cellular Biochemistry 16, 205-212.

RYLANDER, P. N. (1969). Hydrogenolysis. In Catalytic Hydrogenation in Organic Synthesis, pp. 433-487. New York: Academic Press.

SANDFORD, P. A. (1979). Exocellular, microbial polysaccharides. Advances in Carbohydrate Chemistry and Biochemistry 36, 265-313.

Sutherland, I. W. (1985). Biosynthesis and composition of Gramnegative bacterial extracellular and wall polysaccharides. Annual Review of Microbiology 39, 243-270.

TAYLOR, L. R. \& CONRAD, H. E. (1972). Stoichiometric depolymerization of polyuronides and glycosaminoglucuronans to monosaccharide following reduction of their carbodiimide activated carboxyl groups. Biochemistry 11, 1383-1388

TUNG, K. K. \& NoRDIN, J. M. (1968). Structure of the tetrasaccharide produced by the hydrolysis of nigeran by the enzyme mycodextranase. Biochimica et Biophysica Acta 158, 159-156.

VoLK, W. A. (1968). Isolation of D-galacturonic acid 1-phosphate from hydrolysates of cell wall lipopolysaccharide extracted from Xanthomonas campestris. Journal of Bacteriology 95, 782-786.

Wakabayashi, M., Watiz, H. H. \& Fischman, W. H. (1964). Action of $\beta$-glucuronidase on a steroid-enol- $\beta$-glucosiduronic acid. Biochimica et Biophysica Acta 48, 198-199. 